\title{
Recent developments on printed photodetectors for large area and flexible applications
}

J. Oliveira ${ }^{1,2}$, R. Brito-Pereira ${ }^{1}$, B. F. Gonçalves ${ }^{1,3}$, I. Etxebarria ${ }^{4}$, S. LancerosMendez $z^{1,4,5^{*}}$

${ }^{1}$ Center of Physics, University of Minho, 4710-057, Braga, Portugal

${ }^{2}$ Algoritmi Research Center, University of Minho, 4800-058 Guimarães, Portugal

${ }^{3}$ International Iberian Nanotechnology Laboratory, Braga, Portugal

${ }^{4}$ BCMaterials, Basque Centre for Materials, Applications and Nanostructures, UPV/EHU Science Park, 48940 Leioa, Spain

${ }^{5}$ IKERBASQUE, Basque Foundation for Science, 48013 Bilbao, Spain

Keywords: photodetectors; printing technologies; inkjet printing; screen-printing; photodiodes; light detectors; optical devices

\begin{abstract}
New generation photodetectors processed by printed technologies will become a feature of our daily life in the near future. By combining printing technologies with tailored solution processable materials, high efficiency, large area and low-cost devices are achieved. Medical and health care, Internet-Of-Things, Industry 4.0 are strongly increasing fields taking advantage on the developments of printed technologies in general and printed photodetectors, in particular. Applications for consumer electronics such as smart phones, laptops and tables, fingerprint scanning for personal security are some of the most interesting areas to explore in printed photodetectors.
\end{abstract}


This work reviews the recent progress in the development of photodetectors by printing technologies, taking into account both materials and printed technologies.

\section{Introduction}

Optoelectronic materials are being explored for being implemented in sensors, unleashing their potential to transform our lifestyle. Video imaging, optical communications, biomedical imaging, security, night-vision, gas sensing and motion detection are some of the applications with high interest [1].

Nowadays, photodetectors, PD, have a large impact in some of the technologies used in our daily life. PDs are being used in applications such as radiation [2], smoke and flame detection [3] and security inspection [4], among others. Photodetector used for medical X-ray imaging [5] and spectroscopy [6] and also for security systems [7] are some other applications with attracting interest.

The development of novel materials and applications is essential to promote higher performance, sustainability and added value to optoelectronic devices and solutions. Thus, materials are being developed with improved properties, such as, chemical and radiation resistance, wavelength response range, flexibility and integrability, among others [8].

Printed photodetectors can overcome some limitations of current silicon based photodetectors, such as low absorption coefficient and the high temperature, complex and expensive fabrication processes, as well as expand their application range to flexible and large area devices [9]. Solution processable materials allow the fabrication of these devices by printing technologies, such as inkjet printing, spraying and screen printing. Thus, the processing of flexible and stretchable devices, improving their integration and 
allowing production scalability at low fabrication costs is a reality. On other hand, the main limitation of printed photodetectors are the reduced charge transport and stability. $[8]$.

In this review the most relevant works on printed photodetectors and their applications are presented and discussed. Thus, an overview of the state of the art on the different types of printed photodetectors is provided and the main challenges and future needs addressed.

In the following, the state of the art on printed photodetectors is presented, together with the printing technologies used for their processing. The main applications are also summarized and the future challenges and trends outlined. Finally, the main conclusion on the current state of the art and future needs on printed photodetectors are presented.

\section{Printed photodetectors}

To improve flexibility, precision and reduce the fabrication cost in order to achieve new generation of PD, new methods based in printing technologies have been applied [10]. Printing technologies are additive processing techniques that involve a single deposition step per layer usually followed by a drying step $[10,11]$.

There are several printing techniques such as inkjet, screen printing and spray printing that can be used for the fabrication of photodetectors [8]. Printing technologies are significantly growing, as they present many advantages when compared to traditional lithography methods, such as low cost processing, low material waste and the possibility to print into flexible and large areas [12].

\subsection{Main requirements and characteristics of printed photodetectors}

Currently, there are a reasonable number of different printed PD for various applications and fabricated from a variety of materials. Nevetheless, there are still great challenges for 
developing the new generation PDs, when shrinking the size of conventionally used thinfilms hinder their quality or when ultrathin materials become almost transparent losing the ability to gather or absorb light. Thus, a possible way for developing high performance photodetectors arise form the combination of the advantages of both organic (simple solution processability) and inorganic semiconductors (high charge carrier mobility) [13-15]. Depending on the application, a photodetector must fulfill specific requirements to present a good performance, some of these requirements and characteristics being difficult to combine in one type of photodetector, such as high sensibility and high detection bandwidth $[16,17]$.

One of the most important requirement is the sensitivity of the photodetector in a specific spectral region, as determined by the active material. In some cases, the responsivity should be constant or at least well defined within some wavelength range. It can also be important to have zero response in some other wavelength range, e.g., solar-blind detectors are sensitive only to ultraviolet light [17-19]. A PD should be suitable for some range of optical powers: the maximum detected power can be limited by damage issues or by a nonlinear response, whereas the minimum power is typically determined by noise. The magnitude of the dynamic range (specified as the ratio of maximum and minimum detectable power) is often the most important. Some detectors based on photodiodes can exhibit high linearity over a dynamic range of more than $70 \mathrm{~dB}[16,17]$. Concerning the photon detection, a high quantum efficiency is required in order to get a good efficiency conversion of photons into electrons $[17,20]$.

The active area of a detector plays an important role when working with strongly divergent beams from laser diodes. For light sources with very high and/or non-constant beam divergence, it is hardly possible to get all the light into the active area [17, 21, 22]. The detection bandwidth is typically large, beginning at low frequencies and the 
maximum frequency being limited by internal processes as the speed of electric carriers in the semiconductor material, or by the involved electronics [17, 23]. Time response strongly affects the work of a PD used for detecting pulses. Some detectors show a certain "dead time" after the detection of a pulse, where they are not sensitive [16, 17]. Another requirement of photodetectors is the high reliability and also the low noise for reduced errors. In summary, current density, fast responsivity, selected absorption bandwidth, and high quantum efficiency must be considered in order to process optimal PDs [8].

Formulated into functional inks, semiconductors can be processed by means of printing techniques, allowing thus large-area, scalable and flexible device fabrication, opening a complete new pathway for organic electronics and its integration into circuits [8]. An increasing number of printable organic semiconductors and nanoparticles employed as active materials in PD are being proposed in the literature, and this flourishing field is speeding toward scalability and industrial commercialization [8].

In contrast to lithographic methods, mostly employed in the fabrication of inorganic devices via a subtractive approach, printing technologies are additive processing techniques that involve a single deposition step per layer, eventually followed by a drying or sintering step [8].

There are some materials and inks that can be combined and used to produce new types of photodetectors depending to the application. Poly (3,4-ethylenedioxythiophne) poly(styrenesulfonate) (PEDOT:PSS) and poly (3-hexylthiophene)/phenyl-C61-butyric methyl ester (P3HT:PCBM) show good properties as an ink to apply in photodetectors with distinct applications and functions $[12,24]$.

In the majority of the research works silver and gold materials were used in the structure of printed photodetectors due to their stability and conductibility [25]. 


\subsection{Photodetector structures}

Among the diverse light detecting devices and concepts that have been developed over the years, the basic working principle of a PD consists in the process of light absorption which leads to the generation of separated holes and electrons, and their subsequent collection in opposite electrodes. Such mechanism is typical of inorganic $p-n$ junctions as also of donor-acceptor organic semiconductors [17, 26].

The nature of the active materials leads to the charge excitation, dissociation and migration to the respective electrodes. Several studies and reviews have already been reported concerning these processes [8].

A simple sketch of the electronic structure of a PD is shown in Figure 1. In this PD, a semiconductor layer is sandwiched between two conductive layers, a p-layer on top and a n-layer underneath, denominated PIN-heterostructure. The photodiode structure is bonded on top of the interconnect layer where the optical signal propagates before entering the detector. Light is coupled first from the interconnect layer to an InP membrane waveguide, spaced by $300 \mathrm{~nm}(500 \mathrm{~nm})$ when the photonic wire is fabricated in $\mathrm{Si}\left(\mathrm{Si}_{3} \mathrm{~N}_{4}\right)$, then it is absorbed and detected in the PD $[18,25]$.

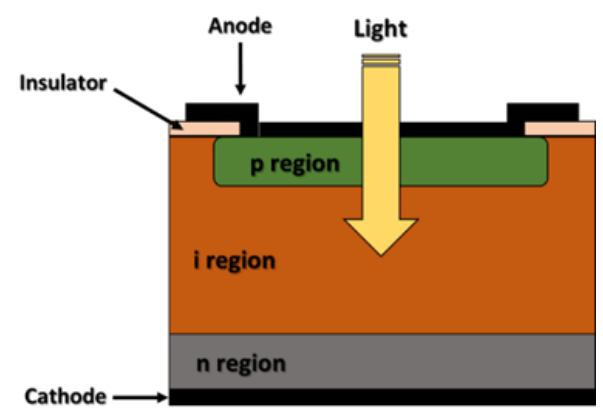

Figure 1. Basic structure of a PIN photodetector.

When a specific energy photon strikes the device, it generates an electron-hole pair. If this phenomenon occurs near the depletion region, the particles of the pair will be accelerated in opposite directions by the electric field. The electrons will migrate to the $n$ side and the holes to the $\mathrm{p}$ side [27-29]. This movement gives rise to a reverse electric 
current in the photodiode. Even in the absence of light, there will always be a reverse current flowing in the photodiode, arising from electron-hole pairs formed spontaneously at the junction with enough energy to reach the terminals $[17,30]$.

Concerning printable PD, the same basic structure is used. However, printing technologies allow new and improved ways to develop PD. They allow the fabrication of well-defined structures as vertical or planar and more efficient three terminals with the addition of a gate electrode. A simple sketch of the electronic structure is shown in Figure 2 [8]. Planar and vertical structures can operate as a photodiode or a photoconductor. Planar structures are easier to fabricate than the vertical ones and do not need a transparent electrode, showing a much larger distance between the electrodes. However, the length can drastically increase the carrier transit time, and its downscaling would require high resolution lithographic processes $[8,31]$. Scaling of the distance is instead more easily achieved in a vertical structure, where the distance between the electrodes is defined by the thickness of a solution processed active layer, providing much faster charge collection. Three terminal devices such as field effect transistors (FETs) can be used as light sensors, typically with the scope of achieving very high responsivity. The main advantage of three-terminal devices has been proven as one of the best candidates for improving low power consumption and high-sensitivity ultraviolet photo- detectors (UV PDs) such as $\mathrm{ZnO}$ based photodetectors.
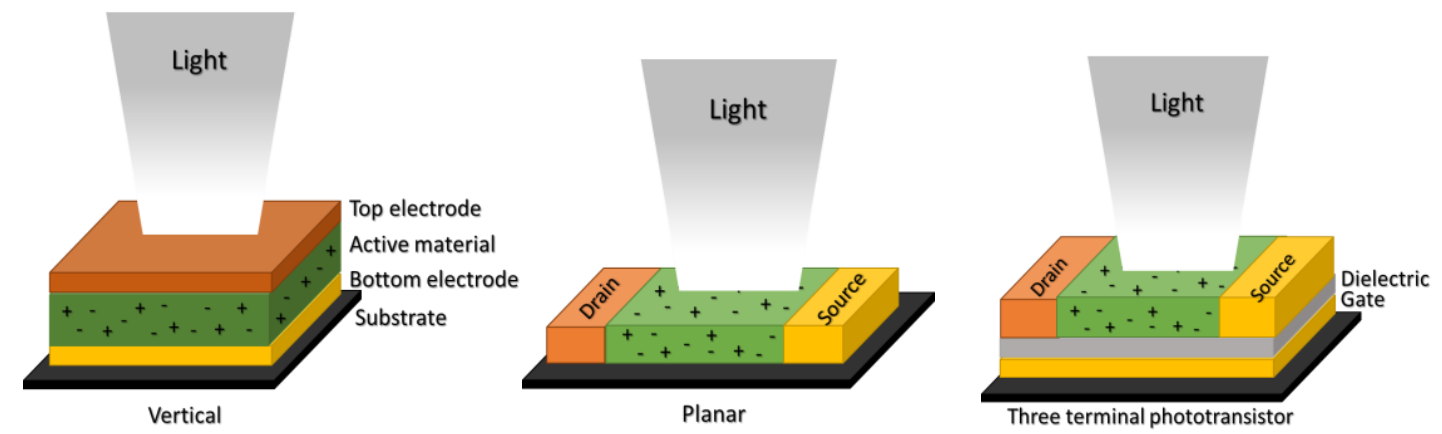

Figure 2. Most commonly printed photodetector structures: Vertical architecture, planar architecture and Three terminal phototransistor device. 
Several layers can be printed subsequently resulting in fully printed devices with excellent optoelectronic performance $[11,31]$. The most common printed PD structure is the vertical topology with the photoactive layer sandwiched between two conductive stripes. This structure is ideal to be processed by printing [24].

Table 1 summarizes the advantages/disadvantages and some generic applications of planar, vertical and three device structures for printed photodetectors.

Table 1. Advantages, disadvantages and aplications of planar, vertical and three device structures.

\begin{tabular}{|c|c|c|c|c|}
\hline Structure & Advantages & Disadvantages & Aplications & Ref. \\
\hline Planar & $\begin{array}{c}\text { - Easy to } \\
\text { construct } \\
\text { - Do not need a } \\
\text { transparent } \\
\text { electrode on the } \\
\text { top }\end{array}$ & $\begin{array}{l}\text { - High distance } \\
\text { between the } \\
\text { electrodes (increment } \\
\text { in the carrier transit } \\
\text { time); } \\
\text { - Downscaling } \\
\text { require high } \\
\text { resolution } \\
\text { lithographic } \\
\text { processes }\end{array}$ & $\begin{array}{c}\text {-Photo-sensing elements for } \\
\text { digital imaging; } \\
\text {-Large-area shortwave } \\
\text { infrared (SWIR) } \\
\text { photodetector arrays } \\
\text { - Optical fiber-based } \\
\text { systems } \\
\text {-Highly sensitive and } \\
\text { applicable at night vision } \\
\text { applications }\end{array}$ & $\begin{array}{c}{[25,} \\
32-36]\end{array}$ \\
\hline Vertical & $\begin{array}{c}\text { - Higher } \\
\text { integration } \\
\text { density } \\
\text { - Higher gain } \\
\text { and fast response } \\
\text { - Small distance } \\
\text { between the } \\
\text { electrodes }\end{array}$ & $\begin{array}{l}\text {-Higher number of } \\
\text { steps for patterning } \\
\text { fabrication }\end{array}$ & $\begin{array}{l}\text { - Imaging detectors } \\
\text { - Position-sensitive } \\
\text { detectors } \\
\text { - IR sensor array }\end{array}$ & $\begin{array}{c}{[30,} \\
37-40]\end{array}$ \\
\hline
\end{tabular}

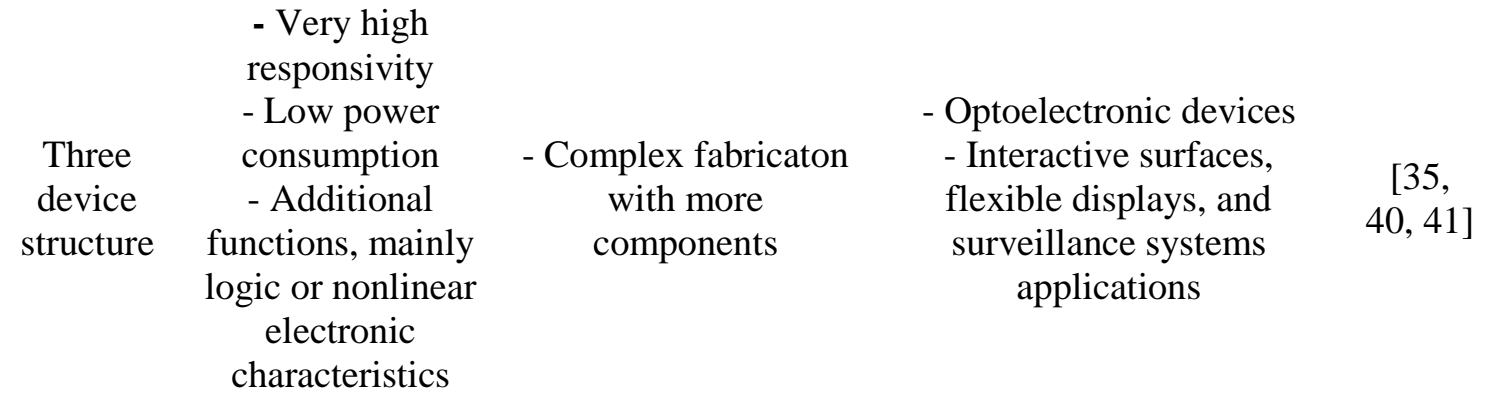




\section{Printed photodetectoers: technologies, materials and performance}

The increasing interest on printing technologies is mainly related to the possibility of layer processing by using a non-complex and cost-effective technique compared to conventional electronics processing. Using additive fabrication processes it is possible to achieve a wide range of new functionalities which will allow new applications and/or the improvement of specific existing applications.

Traditional fabrication techniques such as lithography or thermal evaporation and spin coating (in the case of organic photodetectors), show drawback related to waste of material, energy and time-consuming processes, limitation to small areas or rigid substrates or being very expensive. Printing techniques instead, are additive processing techniques where just the required material amount is used and roll-to-roll compatible. Among solution-processable semiconductors, organic conjugated materials are easily printable by different printing technologies, due to the possibility of tuning the formulations rheology and therefore of engineering inks for different printing techniques and applications. Their low-temperature processing $\left(<150{ }^{\circ} \mathrm{C}\right)$ allows the device fabrication on a vast range of substrates, rigid and flat as well as flexible and curved, opening the way for the development of non-fragile, conformable electronics [8]. The selection of the printing technology is determined by requirements of the printed layers, by the properties of printed materials as well as cost effective and technical considerations of the final application of the printed samples [12].

Some of the most used and attractive printing techniques for printed photodetectors fabrication are inkjet printing, screen printing and spray coating.

Inkjet printing is a non-contact digital process [10, 42]. A pattern is designed in the computer software and the cartridge is moved all over the substrate following the pattern and depositing drops in the required places. This technology allows the design of complex 
patterns with high resolution customizing the material deposition volume and location, i.e. it provides the droplet-on-demand option (DOD). The material is deposited drop by drop, hence, for a continuous path drops need to overlap or touch each other. Multilayers can also be printed, and the thickness of the layer can be controlled either in this way or changing the amount of the material in the drop. Figure 3a shows a sketch of an inkjet printer working principle.
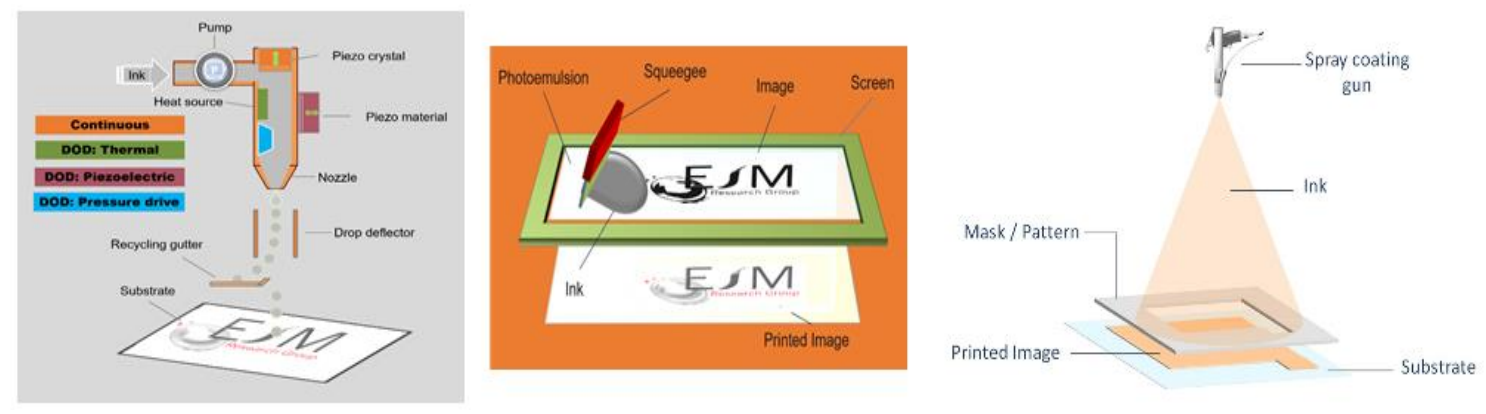

Figure 3. Schematic representation of: a) the inkjet printing process b) screen printing process.; c) spray coating deposition technique. Reproduced with permission [43].

One of the first inkjet printed layers on a photodetector was P3HT:PCBM [11]. The device structure consisted on a glass substrate covered by indium-tin-oxide (ITO), a spin coated PEDOT:PSS layer, an inkjet printed P3HT:PCBM blend and evaporated calcium (Ca) and silver $(\mathrm{Ag})$ layers as the top electrode.

The first fully inkjet printed photodetector was fabricated based on a silver nanoparticles layer on top of the substrate as the bottom electrode, followed by poly $\left(9,9^{\prime}\right.$ dioctylfluorinene-co-bis-N,N'-(4-butylphenyl)-bis-N,N'-phenyl 1,4 phenylenediamine) (PFB) and poly (9, 9'-dioctylfluorene-co-benzothiadiazole) (F8BT) as the active layer and PEDOT:PSS as the top electrode [44].

The performance of the previously described fully inkjet printed photodetector was improved in terms of external quantum efficiency (EQE) by printing a thinner $(\sim 120 \mathrm{~nm})$ P3HT:PCBM layer as the active material [12]. Moreover, by introducing a 
polyethylenimine (PEIE) layer (by spin coating) between the photoactive layer and the silver electrode, the cathode work function was reduced, and the wettability of the photoactive material was improved.

Further, a fully inkjet printed organic photodetector based on narrow band gap conjugated molecules [24] was demonstrated showing that the use of small molecules allows to improve the spectral responsivity of the detector. Recentely, an all-printed and flexible indirect X-ray detector was successsfully achieved by using a combination of screen and inkjet printing. Polymer based scintillator inks were used to print the photodetector TFTbased array with a promising performance for flexible optoelectronics with a low-cost and large-area [45].

Screen printing is a printing technique (Figure $\mathbf{3 b}$ ) where a mesh is used in order to transfer the pattern to the substrate [46]. A squeegee is then moved all over the substrate along the mesh and the ink in transferred to the substrate though the apertures of the mesh. A screen printed $\mathrm{CdS}: \mathrm{CdO}$ structure was reported as suitable to be used as a photodetector [47]. A porous $\mathrm{CdS}: \mathrm{CdO}$ composite structure was developed by screen printing and sintering of CdS in air.

Also mercuric iodide $\left(\mathrm{HgI}_{2}\right)$ films were processed for X-ray detection [48-50]. The X-ray sensor with an oxide thin-film transistor backplane and $\mathrm{HgI}_{2}$ sensing material displayed outstanding image quality under a low X-ray exposure and a low electric field [51].

Similar to inkjet printing, spray coating technique (Figure 3c) is not in direct contact with the substrate and the material is deposited in micron size droplets. The liquid coming out from a nozzle is atomized by ultrasonic vibrations or pressure and the droplets are deposited randomly. An inert gas like nitrogen for example is used as a carrier gas. Depending on the solution flow rate and the moving speed of the nozzle, the thickness of 
the layer can be tunned. This deposition method does not allow complex patterns unless a mask with the desired pattern is used.

Fully spray coated photodiodes based on P3HT:PCBM has been presented [37] showing that despite the larger surface roughness with respect to films obtained by other techniques such as e spin coating and doctor blade, the performance was improved, with responsivities of $0.36 \mathrm{~A} / \mathrm{W}$ and lifetime beyond 1 year.

Hybrid CMOS-imager with a solution processable polymer as photoactive layer was showed in [52]. A P3HT:PCBM layer was deposited by spray coating on top of a silicon based CMOS-pixel array. PEDOT:PSS, PEDOT:PSS/Graphene and carbon nanotubes have also been deposited by spray coating in organic photodetectors as transparent electrodes [53-58]. In this way P3HT:PCBM based photodetectors were fabricated on PET substrates by spray coating. Several groups have also investigated on spray coated $\mathrm{ZnO}$, that was used as electrode and active layer [59, 60]. Finally, spray coated inorganic materials based on aqueous HgTe-QD have been used for the development of infrared photodetectors [34].

Together to the abovementioned representative examples, Table 2 reports on the main printing technologies, the material used, device structure and mains characteristics and applications of the most significant printed PD. 
Table 2. Printed photodetectors by printing technologies. All images reproduced with permission.

\begin{tabular}{|c|c|c|c|c|c|}
\hline $\begin{array}{l}\text { Printing } \\
\text { Technology }\end{array}$ & $\begin{array}{l}\text { Device } \\
\text { material }\end{array}$ & $\begin{array}{l}\text { Device } \\
\text { Structure }\end{array}$ & $\begin{array}{c}\text { Responsivity } \\
\text { R (A/W) }\end{array}$ & Application & Ref. \\
\hline Inkjet & $\begin{array}{c}\mathrm{Au} / \mathrm{TIPS} \\
\text { pentacene/Au } \\
\text { phototransisto } \\
\text { r with } \\
\text { ITO/PVP as } \\
\text { back gate }\end{array}$ & & 0.11 & $\begin{array}{l}\text { Low-cost and } \\
\text { high- } \\
\text { performance } \\
\text { photo-sensing } \\
\text { element for } \\
\text { digital imaging } \\
\text { applications } \\
\end{array}$ & [33] \\
\hline Inkjet & $\begin{array}{c}\text { PEN/Ag/P3H } \\
\text { T:PCBM/PED } \\
\text { OT:PSS/Ag }\end{array}$ & & 0.39 & $\begin{array}{l}\text { Integration in } \\
\text { pixels of future } \\
\text { flexible and } \\
\text { large-area } \\
\text { digital imagers } \\
\text { manufactured } \\
\text { on plastic foils }\end{array}$ & [12] \\
\hline Inkjet & $\begin{array}{l}\text { ITO/PEDOT: } \\
\text { PSS/ } \\
\text { P3HT:PCBM } \\
\text { /Al }\end{array}$ & & 0.25 & $\begin{array}{c}\text { Detection of } \\
\text { bacterial } \\
\text { superantigens } \\
\text { as } \\
\text { Staphylococcal } \\
\text { enterotoxin } B \\
\text { at low } \\
\text { concentrations }\end{array}$ & [61] \\
\hline Inkjet & $\begin{array}{c}\mathrm{Au} / \mathrm{HgTe} \\
\text { Nanocristals/ } \\
\mathrm{Au}\end{array}$ & & 0.65 & $\begin{array}{c}\text { Highly } \\
\text { sensitive and } \\
\text { applicable at } \\
\text { night vision } \\
\text { applications. }\end{array}$ & [25] \\
\hline Inkjet & $\begin{array}{l}\mathrm{Au} / \mathrm{PDPPT} \mathrm{PBB} \\
\mathrm{T} / \mathrm{Au} / \mathrm{SiO}_{2} / \mathrm{Si}\end{array}$ & & $10^{6}$ & $\begin{array}{l}\text { Light triggered } \\
\text { memory } \\
\text { device }\end{array}$ & [62] \\
\hline Inkjet & $\begin{array}{l}\mathrm{Ag} / \mathrm{CNT} / \mathrm{Ag} \\
\text { photodetector }\end{array}$ & (a) & 0.5 & $\begin{array}{l}\text { Low-cost fully } \\
\text { integrated } \\
\text { CNT based IR } \\
\text { sensor array. }\end{array}$ & [63] \\
\hline Inkjet & $\begin{array}{l}\mathrm{AgNW} / \mathrm{TiO}_{2} \\
\mathrm{NW} / \mathrm{AgNW} \\
\text { photodetector }\end{array}$ & & - & $\begin{array}{l}\text { Photoelectric } \\
\text { devices for } \\
\text { transparent } \\
\text { microelectroni } \\
\text { c applications. }\end{array}$ & [32] \\
\hline
\end{tabular}




\begin{tabular}{|c|c|c|c|c|c|}
\hline Injekt & $\begin{array}{c}10 \mathrm{mg} / \mathrm{ml} \\
\text { graphene/MoS } \\
2 \text { in } 10 \mathrm{ml} \mathrm{C} / \mathrm{T} \\
\text { with } 2.5 \mathrm{wt} \% \\
\text { EC) }\end{array}$ & $=4 \frac{1 \mathrm{~mm}}{2}$ & 0.30 & $\begin{array}{l}\text { Age-related } \\
\text { macular } \\
\text { degeneration } \\
\text { and retine } \\
\text { deseases. }\end{array}$ & [36] \\
\hline Injekt & $\begin{array}{l}\text { BP/graphene/ } \\
\mathrm{Si}\end{array}$ & & 0.164 & $\begin{array}{l}\text { High } \\
\text { performance } \\
\text { broadband for } \\
\text { optoelectronic } \\
\text { applications }\end{array}$ & [64] \\
\hline Inkjet & $\begin{array}{c}\text { PEN/PEDOT: } \\
\text { PSS/PFN/T1: } \\
\text { P3HT: } \\
\text { PC70BM/PE } \\
\text { DOT:PSS }\end{array}$ & & - & $\begin{array}{l}\text { Applied in } \\
\text { interactive } \\
\text { surfaces and } \\
\text { surveillance } \\
\quad \text { systems }\end{array}$ & [41] \\
\hline $\begin{array}{l}\text { Screen } \\
\text { Printing }\end{array}$ & $\mathrm{CH}_{3} \mathrm{NH}_{3} \mathrm{PbI}_{3}$ & & - & $\begin{array}{l}\text { Can be applied } \\
\text { in solar cells }\end{array}$ & [35] \\
\hline $\begin{array}{l}\text { Screen } \\
\text { Printing }\end{array}$ & $\begin{array}{l}\text { ITO/PEIE/PC } \\
\text { DTBT:PC60B } \\
\text { M/ } \\
\text { PEDOT:PSS }\end{array}$ & & 0.34 & $\begin{array}{c}\text { Excellent } \\
\text { performance in } \\
\text { terms of dark } \\
\text { current and } \\
\text { quantum yield }\end{array}$ & [65] \\
\hline $\begin{array}{l}\text { Screen } \\
\text { Printing }\end{array}$ & $\begin{array}{c}\text { PEDOT:PSS: } \\
\text { PEIE/PCDTB } \\
\text { T:PC }{ }_{71} \mathrm{BM} / \mathrm{PE} \\
\text { DOT:PSSS }\end{array}$ & $\begin{array}{l}\text { Anode PEDOT:PSS } \\
\text { Active laver } \\
\text { Cathode PEDOT: } \\
\text { Plastic substrate }\end{array}$ & - & $\begin{array}{l}\text { Can replace } \\
\text { the silicon } \\
\text { photodiodes } \\
\text { used in image } \\
\text { sensors }\end{array}$ & [66] \\
\hline Spray & $\begin{array}{c}\text { ITO/ } \\
\text { PEDOT:PSS } \\
\text { /P3HT:PCBM } \\
\text { /Ca/Ag }\end{array}$ & & 0.36 & $\begin{array}{l}\text { Imaging } \\
\text { applications or } \\
\text { position- } \\
\text { sensitive } \\
\text { detectors }\end{array}$ & [37] \\
\hline Spray & $\begin{array}{c}\text { PEDOT:PSS/ } \\
\text { Al/ } \\
\text { P3HT:PCBM }\end{array}$ & 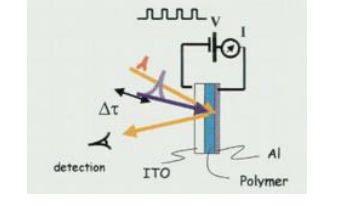 & 0.01 & $\begin{array}{c}\text { Applied in } \\
\text { optical fiber- } \\
\text { based systems }\end{array}$ & $\begin{array}{l}{[67,} \\
68]\end{array}$ \\
\hline Spray & $\begin{array}{l}\mathrm{Au} / \mathrm{HgTe} \mathrm{QD} \\
\text { films/Au }\end{array}$ & - & 0.5 & $\begin{array}{l}\text { Applied in } \\
\text { large-area } \\
\text { SWIR } \\
\text { photodetector } \\
\text { arrays }\end{array}$ & [34] \\
\hline
\end{tabular}


Some important aspects must be taken into consideration with respect to printable materials such as viscosity, surface tension, and solid content, among others.

In particular, each printing technology has important limitations in terms of viscosity, resolution and maximum size of the solid content, among others (Table 3).

Table 3. Printing technologies characteristics and ink/substrate requirements $[43,46]$.

\begin{tabular}{|c|c|c|c|c|c|c|}
\hline $\begin{array}{l}\text { Printing } \\
\text { technology }\end{array}$ & Advantages & $\begin{array}{l}\text { Disadvanta } \\
\text { ges }\end{array}$ & $\begin{array}{c}\text { Viscosity } \\
\text { (mPas) }\end{array}$ & $\begin{array}{c}\text { Max. } \\
\text { particle } \\
\text { diameter } \\
(\mu \mathrm{m})\end{array}$ & $\begin{array}{c}\text { Film } \\
\text { thickness } \\
(\mu \mathrm{m})\end{array}$ & $\begin{array}{l}\text { Resolution } \\
\qquad(\mu \mathrm{m})\end{array}$ \\
\hline $\begin{array}{l}\text { Inkjet } \\
\text { (No } \\
\text { contact) }\end{array}$ & $\begin{array}{l}\text {-Low ink } \\
\text { amount and } \\
\text { viscosity }\end{array}$ & $\begin{array}{l}\text { - Low } \\
\text { throughput } \\
\text {-Nozzle } \\
\text { reliability }\end{array}$ & $8-20$ & 0.2 & $0.1-20$ & $20-50$ \\
\hline $\begin{array}{l}\text { Screen } \\
\text { printing } \\
\text { (Contact) }\end{array}$ & $\begin{array}{c}\text {-Robust } \\
\text {-Simple } \\
\text {-Thick layers }\end{array}$ & $\begin{array}{l}\text { - Low } \\
\text { throughput } \\
\text { and } \\
\text { resolution } \\
\text {-High ink } \\
\text { viscosity }\end{array}$ & $\begin{array}{l}200- \\
10000\end{array}$ & 70 & $5-20$ & $50-100$ \\
\hline $\begin{array}{c}\text { Spray } \\
\text { (No } \\
\text { contact) }\end{array}$ & $\begin{array}{l}\text { - High } \\
\text { throughput } \\
\text { and thickness } \\
\text { variation }\end{array}$ & $\begin{array}{l}\text {-Low } \\
\text { resolution }\end{array}$ & $1-1000$ & 10 & $7.5-10$ & 1000 \\
\hline
\end{tabular}

In conclusion, inkjet technology is suitable for high resolution printing patterns with the requirement of using low viscosity inks. For lower resolution patterns, simple printing technologies as screen printing and spray could be used. It is crucial that the ink 
parameters (viscosity/surface tension) match the printing technology to be used to acquire a good printing pattern.Thus, together to accomplish with the processing requirements, each printable layer of a photodetector has some specific characteristics and depending of the material used in the formulation of the inks, the final yield and the possible application of the device will be determined. Table 4 shows this difference and the materials applied in the layers, as conductive, semiconductive or dielectric/insulator of some of the aforementioned photodetectors.

Table 4. Materials characteristics for printable photodetectors.

\begin{tabular}{|c|c|c|c|c|}
\hline Layers (Inks) & $\begin{array}{l}\text { Deposition } \\
\text { technique }\end{array}$ & Material & $\begin{array}{l}\text { Characteristics } \\
\text { and } \\
\text { performance } \\
\end{array}$ & Ref. \\
\hline Conductive & Spin-coating & $\begin{array}{l}\text { Commercial Fluorine- } \\
\text { doped tin oxide (FTO) } \\
\text { glasses }\end{array}$ & $\begin{array}{c}\text { Sheet } \\
\text { resistance: } 14 \\
\Omega / \text { sq }\end{array}$ & \multirow{3}{*}{ [35] } \\
\hline $\begin{array}{c}\text { Semiconductive } \\
\text { (active } \\
\text { material) }\end{array}$ & Screen printing & $\begin{array}{l}\text { Synthesis of perovskite thin } \\
\text { films by dipping } \mathrm{PbO} \text { thin } \\
\text { films, previously prepared, } \\
\text { into } \mathrm{CH}_{3} \mathrm{NH}_{3} \mathrm{I} \text { with 2- } \\
\text { propanol. } \\
\mathrm{PbO} \text { thin films prepared by } \\
\text { a solvent precipitation } \\
\text { method }\left(\mathrm{Pb}\left(\mathrm{NO}_{3}\right)_{2}+\right. \\
\mathrm{NaBH}_{4}+\mathrm{Triton}-\mathrm{X}-100+ \\
\mathrm{NaClO}) \text { and mixed with } \\
\text { ethanol, ethyl cellulose and } \\
\text { terpilenol. }\end{array}$ & $\begin{array}{l}\text { Thickness of } \\
\text { the film: } 700- \\
\quad 800 \mathrm{~nm}\end{array}$ & \\
\hline Dielectric & & --- & --- & \\
\hline Conductive & $\begin{array}{c}\text { Photolithography, } \\
\text { thermal } \\
\text { deposition and } \\
\text { lift-off }\end{array}$ & $\begin{array}{l}\text { Gold interdigitated } \\
\text { electrodes }\end{array}$ & $\begin{array}{c}\text { Metal } \\
\text { thickness: } 30 \\
\text { nm }\end{array}$ & \multirow{3}{*}{ [34] } \\
\hline $\begin{array}{c}\text { Semiconductive } \\
\text { (active } \\
\text { material) }\end{array}$ & Spray & $\begin{array}{c}\text { HgTe quantum dots } \\
\text { synthesized in aqueous } \\
\text { solution via a reaction } \\
\text { between } \mathrm{Hg}\left(\mathrm{ClO}_{4}\right)_{2} \text { and } \\
\mathrm{H}_{2} \text { Te gas in the presence of } \\
\text { 1-thioglycerol) }\end{array}$ & $\begin{array}{l}\text { Layer } \\
\text { thickness: } 150- \\
200 \mathrm{~nm}\end{array}$ & \\
\hline Dielectric & & --- & --- & \\
\hline Conductive & Spray & $\begin{array}{l}\text { Anode: Indium tin oxide } \\
\text { (ITO) coated glass with } \\
\text { commercial PEDOT:PSS } \\
\text { as a hole conductor }\end{array}$ & $\begin{array}{c}\text { Anode sheet } \\
\text { resistance: }<15 \\
\Omega / \text { sq }\end{array}$ & [37] \\
\hline
\end{tabular}




\begin{tabular}{|c|c|c|c|c|}
\hline & & Cathode: $\mathrm{Ca}$ and $\mathrm{Ag}$ & $\begin{array}{c}\text { Cathode } \\
\text { transmission: } \\
65 \% \text { at } 532 \mathrm{~nm}\end{array}$ & \\
\hline $\begin{array}{l}\text { Semiconductive } \\
\text { (active } \\
\text { material) }\end{array}$ & Spray & $\begin{array}{l}\text { Bulk heterejunction diode } \\
\text { from a xylene solution of } \\
\text { regioregular rr-P3HT and } \\
\text { PCBM }\end{array}$ & $\begin{array}{l}\text { rr-P3HT:PCBM } \\
\text { ratio of 1:0.75 }\end{array}$ & \\
\hline Dielectric & & --- & --- & \\
\hline Conductive & Sputtering & $\begin{array}{c}\text { ITO gate electrode } \\
\text { For source/drain electrode a } \\
\text { suspended top-contact } \\
\text { electrode structure was } \\
\text { fabricated with } \mathrm{Cr} \text { and } \mathrm{Au} \\
\text { bi-layers }\end{array}$ & $\begin{array}{l}\text { ITO thickness: } \\
100 \mathrm{~nm} \\
\text { Cr and } \mathrm{Au} \\
\text { thickness: } 50 \\
\text { nm each }\end{array}$ & \multirow{3}{*}{ [41] } \\
\hline $\begin{array}{l}\text { Semiconductive } \\
\text { (active } \\
\text { material) }\end{array}$ & Inkjet & $\begin{array}{l}\text { Organic semiconductor ink } \\
\text { of } 6,13- \\
\text { bis(triisopropylsilylethynyl) } \\
\text { (TIPS)-pentacene prepared } \\
\text { from anisole solution }\end{array}$ & --- & \\
\hline Dielectric & Spin-coating & $\begin{array}{c}\text { Organic gate insulator of } \\
\text { poly-4-vinylphenol (PVP) } \\
\text { prepared with PVP powder } \\
\text { mixed with poly(melamine- } \\
\text { co-formaldehyde) } \\
\text { methylated in propylene } \\
\text { glycol monomethyl ether } \\
\text { acetate } \\
\end{array}$ & --- & \\
\hline Conductive & Inkjet & $\begin{array}{c}\text { Graphene electrodes ink } \\
\text { (graphene in } \\
\text { cyclohexanone/terpineol } \\
\text { (CT) with ethyl cellulose } \\
\text { (EC)) }\end{array}$ & $\begin{array}{l}\text { Ink viscosity: } \\
\sim 12 \mathrm{cP}\end{array}$ & \multirow[t]{3}{*}[36]{} \\
\hline $\begin{array}{l}\text { Semiconductive } \\
\text { (active } \\
\text { material) }\end{array}$ & Inkjet & $\mathrm{MoS}_{2}$ in CT with EC & $\begin{array}{c}\text { CT ratio: } 7: 3 \\
\text { Ink viscosity: } \\
\sim 12 \mathrm{cP}\end{array}$ & \\
\hline Dielectric & & --- & --- & \\
\hline Conductive & $\begin{array}{l}\text { Inkjet and vacuum } \\
\text { deposition }\end{array}$ & $\begin{array}{c}\text { Ag contact with } \\
\text { PEDOT:PSS (CLENOS P } \\
\text { Jet } N) \text { stripes }\end{array}$ & --- & \multirow{3}{*}[61]{} \\
\hline $\begin{array}{l}\text { Semiconductive } \\
\text { (active } \\
\text { material) }\end{array}$ & $\begin{array}{l}\text { Inkjet and spin- } \\
\text { coating }\end{array}$ & $\begin{array}{c}\text { Commercial P3HT } \\
\text { andcommercial } \mathrm{PC}_{61} \mathrm{BM} \\
\text { dissolved in 1,2- } \\
\text { dichlorobenzene and } \\
\text { mesitylene }\end{array}$ & $\begin{array}{c}\text { P3HT: RR = } \\
96.6 \%, \mathrm{MW}= \\
65500) \\
\\
\mathrm{PC}_{61} \mathrm{BM} \text { purity } \\
>99.5 \%\end{array}$ & \\
\hline Dielectric & & --- & --- & \\
\hline Conductive & Inkjet & $\begin{array}{c}\text { Commercial PEDOT:PSS } \\
\qquad \text { Ag S/D electrodes }\end{array}$ & $\begin{array}{l}\text { Ag content: } 39 \\
\text { wt } \% \text {, viscosity: } \\
1.5 \text { cPs at } 0.4 \\
\text { rpm, surface }\end{array}$ & [33] \\
\hline
\end{tabular}


tension: 25.8

$\mathrm{mN}$ m1 ; ANP

Co.)

\begin{tabular}{|c|c|c|c|c|}
\hline $\begin{array}{c}\text { Semiconductive } \\
\text { (active } \\
\text { material) }\end{array}$ & Inkjet & $\begin{array}{c}\text { poly[2,5-bis }(2- \\
\text { octyldodecyl)pyrrolo[3,4-c] } \\
\text { pyrrole- } 1,4(2 \mathrm{H}, 5 \mathrm{H}) \text {-dione- } \\
\text { (E)-1,2-di(2,20 -bithiophen- } \\
\text { 5-yl) ethene] } \\
\text { PDPP-DBTE }\end{array}$ & --- & \\
\hline Dielectric & Bar-coating & $\begin{array}{l}\text { Commercial Poly(methyl } \\
\text { methacrylate) (PMMA) }\end{array}$ & $\begin{array}{c}\mathrm{MW}=120 \mathrm{k}, \\
\text { dielectric } \\
\text { constant } \varepsilon \mathrm{r}= \\
3.5)\end{array}$ & \\
\hline Conductive & Inkjet & PEDOT:PSS and Al & --- & \\
\hline $\begin{array}{c}\text { Semiconductive } \\
\text { (active } \\
\text { material) }\end{array}$ & Inkjet & P3HT:PC 61 BM & --- & [12] \\
\hline Dielectric & & --- & --- & \\
\hline
\end{tabular}

\begin{tabular}{|c|c|c|c|c|}
\hline Conductive & $\begin{array}{c}\text { Optical } \\
\text { lithography and } \\
\text { evaporation }\end{array}$ & $\mathrm{TI}$ and $\mathrm{Au}$ electrodes & --- & \multirow{3}{*}{ [25] } \\
\hline $\begin{array}{l}\text { Semiconductive } \\
\text { (active } \\
\text { material) }\end{array}$ & Inkjet & $\begin{array}{c}\text { Hydrophobic } \mathrm{HgTe} \\
\text { nanocrystals (NC) } \\
\text { Synthesized in aqueous } \\
\text { solution at room } \\
\text { temperature via a reaction } \\
\text { between } \mathrm{Hg}\left(\mathrm{ClO}_{4}\right) 2 \text { and } \\
\mathrm{H}_{2} \mathrm{Te} \text { gas in the presence of } \\
\text { short chain hydrophilic } \\
\text { thiols such as thioglycerol } \\
\text { or mercaptoethanola- mine } \\
\text { as stabilizer }\end{array}$ & --- & \\
\hline Dielectric & & --- & --- & \\
\hline Conductive & $\begin{array}{c}\text { Thermal } \\
\text { evaporation }\end{array}$ & $3 \mathrm{~nm} \mathrm{Ti}$ and $30 \mathrm{~nm} \mathrm{Au}$ & & \multirow{3}{*}{ [62] } \\
\hline $\begin{array}{c}\text { Semiconductive } \\
\text { (active } \\
\text { material) }\end{array}$ & Inkjet & $\begin{array}{c}\text { PDPPTzBT } \\
\text { (diketopyrrolopyrrole- } \\
\text { thiazolothiazole copolymer) }\end{array}$ & $\begin{array}{c}\text { Hole mobility } \\
\text { of } 1.80 \mathrm{~cm}^{2} \\
\mathrm{~V}^{-1} \mathrm{~s}^{-1} \\
\text { on/off ratio of } \\
10^{8}\end{array}$ & \\
\hline Dielectric & $\begin{array}{l}\text { Spin-coating and } \\
\text { inkjet }\end{array}$ & $\begin{array}{c}3 \mathrm{~nm} \text { of PMMA } \\
300 \mathrm{~nm} \text { silica (dielectric) }\end{array}$ & $\begin{array}{l}\mathrm{M}_{\mathrm{W}}(120 \mathrm{KDa}, \\
350 \mathrm{KDa}, 550 \\
\mathrm{KDa} \text { and } 996 \\
\mathrm{KDa})\end{array}$ & \\
\hline Conductive & Inkjet & Ag electrodes & --- & [63] \\
\hline
\end{tabular}




\begin{tabular}{|c|c|c|c|c|}
\hline $\begin{array}{l}\text { Semiconductive } \\
\text { (active } \\
\text { material) }\end{array}$ & Inkjet & $\begin{array}{l}\text { Commercial multiwalled } \\
\text { MW carbon nanotubes } \\
\text { CVD-grown }\end{array}$ & $\begin{array}{l}\text { Diameters in } \\
\text { the range of } 10- \\
20 \mathrm{~nm} \text { with a } \\
\text { length between } \\
1 \text { and } 10 \mathrm{~mm}\end{array}$ & \\
\hline Dielectric & & --- & --- & \\
\hline Conductive & Inkjet & AgNW electrodes & $\begin{array}{l}\text { Five layers of } \\
\text { AgNW to } \\
\text { ensure the } \\
\text { efficiency of } \\
\text { photocurrent } \\
\text { collection. } \\
\text { (Sheet } \\
\text { resistance: } 10 \\
\Omega / \text { sq) }\end{array}$ & \multirow[t]{3}{*}{ [32] } \\
\hline $\begin{array}{c}\text { Semiconductive } \\
\text { (active } \\
\text { material) }\end{array}$ & Inkjet & $\begin{array}{c}\text { Titanium dioxide }\left(\mathrm{TiO}_{2}\right) \\
\text { nanowires }\end{array}$ & $\begin{array}{l}\text { Good electron } \\
\text { mobility }\end{array}$ & \\
\hline Dielectric & & --- & --- & \\
\hline Conductive & $\begin{array}{c}\text { Chemical vapour } \\
\text { deposition }\end{array}$ & Graphene & --- & \multirow{3}{*}{ [64] } \\
\hline $\begin{array}{l}\text { Semiconductive } \\
\text { (active } \\
\text { material) }\end{array}$ & Inkjet & Black phosphorus ink & $\begin{array}{l}\text { Low oxidation } \\
\text { proportion } \\
(4.2 \%)\end{array}$ & \\
\hline Dielectric & & --- & --- & \\
\hline
\end{tabular}

From Table 4 it is concluded that the existing inks despite to show specific similar characteristics, differ in many key issues, such as funcionality, performance and materials composition that are more suitable for the specific application. Thus, a careful selection of the appropriated inks is critical by taking into acount the main function of the materials compositions for each specified layer that will be printed, as well as the compatibility of the different layers. By this state of art it can also be concluded that there are few fullyprinted PD. With the use of printing technologies, low-cost and flexible PD with large scalability can be obtained. 


\section{Summary, final remarks and future trends}

This review reports on the main materials, structures and techniques used for the development of printed photodetectors by inkjet, spray and screen printing technologies and their applications.

Printed photodetectors show increasing interest as printing is a low cost and roll to roll compatible process. The increased amount of research works and demonstration of the use of printed photodetectors in a wide-range of applications mirrors the high interest of the scientists and industries in their development and application. PD have a large range of technological applications in fast growing areas such as telecommunications, sensors, and medical devices, among others [17, 69]. These printed devices can be used in the automotive industry - for the detection of objects to avoid collisions-, in factories - for electrical arc detection, automatically cutting off the current where arcing occurs-, in a process control -as a position sensor -, in recycling plants, in non-destructive testing units and as detector systems that can endure extreme environmental conditions [70].

The well-known silicon-based photodetectors are manufactured using the timeconsuming, expensive and complicated fabrication process that involve several steps [71]. Moreover, these sensors are rigid and brittle, with thick layers and limited to small areas.

Printing appears as the solution to these technological disadvantages, offering several advantages such as high speed, low cost, possibility of room temperature processing, and applicability to flexible substrates. Printing technologies also provide direct patterning of a surface eliminating the need of expensive masks and opening the door to complex patterns and the choice of deposited materials. 
The key issues hindering further development are the improvement of novel materials and inks with tailored functional and processability characteristics, as well as to develop new and more flexible processing ways to directly print photodetectors.

It should also be noted that most of new products from printing technologies must be based on green solvents.

Despite all the advantages of printed photodetectors, the vast majority of the current commercially available optical devices are not based on printed technologies.

Applications such as flexible displays applied on medical imaging, diagnostics devices, identification tags and solar cells represent some consumer areas of higher and relevant interest for printed photodetectors. Photodetectors can be easily integrated into polymer films solutions which can be applied to flexible surfaces.

Medical and health care, Internet-Of-Things, Industry 4.0 are some of the examples of the areas where the printed photodetectors can have an important role, allowing the creation of high value services for these industries. New user interfaces based on gesture recognition for connected objects, consumer products, intuitive user interfaces are some examples to take into account. Concerning the medical applications, large area X-ray medical imaging for applied to digital imaging body and dental are one of the most investigated applications on this area.

Applications for consumer electronics such as smart phones, laptops and tablets, fingerprint scanning for personal security are one of the most interesting areas to explore in terms of printed photodetectors. Regarding to diagnostic industry, one of the most relevant application should pass for the link of a photodetectors array for detection associated with microfluidics and Lab-on-Chip technologies, which can show a very important role on the healthy science.

In this review we have attempted to summarize the last important works in printed optical 
devices with a special attention on printed photodetectors.

\section{AUTHOR INFORMATION}

\section{Corresponding Author}

senentxu.lanceros@bcmaterials.net

\section{Author Contributions}

The manuscript was written through contributions of all authors. All authors have given approval to the final version of the manuscript.

\section{Funding Sources}

Portuguese Foundation for Science and Technology (FCT)

Basque Government Industry Department

Spanish Ministry of Economy and Competitiveness

\section{ACKNOWLEDGMENTS}

This work was supported by the Portuguese Foundation for Science and Technology (FCT) in the framework of the Strategic Funding UID/FIS/04650/2013 and projects PTDC/EEI-SII/5582/2014 and PTDC/CTM-ENE/5387/2014. J. Oliveira thanks the FCT SFRH/BD/98219/2013 grant. B.F. Gonçalves thanks the FCT SFRH/BD/121780/2016 grant. The authors thank financial support from the Basque Government Industry Department under the ELKARTEK and HAZITEK programs and funding by the Spanish Ministry of Economy and Competitiveness (MINECO) through the project MAT201676039-C4-3-R. 


\section{Bibliography}

[1] M.A. Boles, D. Ling, T. Hyeon, D.V. Talapin, The surface science of nanocrystals, Nature Materials 15 (2016) 141. https://doi.org/10.1038/nmat4526.

[2] V. Ryzhii, M. Ryzhii, D. Svintsov, V. Leiman, V. Mitin, M.S. Shur, T. Otsuji, Infrared photodetectors based on graphene van der Waals heterostructures, Infrared Physics \& Technology 84 (2017) 72-81. https://doi.org/10.1016/j.infrared.2017.01.016.

[3] P. Cheong, K. Chang, Y. Lai, S. Ho, I. Sou, K. Tam, A ZigBee-Based Wireless Sensor Network Node for Ultraviolet Detection of Flame, IEEE Transactions on Industrial Electronics 58(11) (2011) 5271-5277. https://doi.org/10.1109/TIE.2011.2119455.

[4] M. Furchi, A. Urich, A. Pospischil, G. Lilley, K. Unterrainer, H. Detz, P. Klang, A.M. Andrews, W. Schrenk, G. Strasser, T. Mueller, Microcavity-Integrated Graphene Photodetector, Nano Letters 12(6) (2012) 2773-2777. https://doi.org/10.1021/nl204512x.

[5] G.N. Ankah, P. Büchele, K. Poulsen, T. Rauch, S.F. Tedde, C. Gimmler, O. Schmidt, T. Kraus, $\mathrm{PbS}$ quantum dot based hybrid-organic photodetectors for $\mathrm{X}$-ray sensing, Organic Electronics 33 (2016) 201-206. https://doi.org/10.1016/j.orgel.2016.03.023.

[6] C.-H. Liu, Y.-C. Chang, T.B. Norris, Z. Zhong, Graphene photodetectors with ultra-broadband and high responsivity at room temperature, Nature Nanotechnology 9 (2014) 273. https://doi.org/10.1038/nnano.2014.31.

[7] W. Zheng, R. Lin, Z. Zhang, Q. Liao, J. Liu, F. Huang, An ultrafast-temporally-responsive flexible photodetector with high sensitivity based on high-crystallinity organic-inorganic perovskite nanoflake, Nanoscale 9(34) (2017) 12718-12726. https://doi.org/10.1039/C7NR04395C.

[8] G. Pace, A. Grimoldi, M. Sampietro, D. Natali, M. Caironi, Printed photodetectors, Semiconductor Science and Technology 30(10) (2015). https://doi.org/10.1088/02681242/30/10/104006.

[9] A. Nathan, A. Ahnood, M.T. Cole, S. Lee, Y. Suzuki, P. Hiralal, F. Bonaccorso, T. Hasan, L. Garcia-Gancedo, A. Dyadyusha, S. Haque, P. Andrew, S. Hofmann, J. Moultrie, D. Chu, A.J. Flewitt, A.C. Ferrari, M.J. Kelly, J. Robertson, G.A.J. Amaratunga, W.I. Milne, Flexible electronics: The next ubiquitous platform, Proceedings of the IEEE 100(SPL CONTENT) (2012) 1486-1517. https://doi.org/10.1109/JPROC.2012.2190168.

[10] H. Castro, E. Sowade, J. Rocha, P. Alpuim, S. Lanceros-Méndez, R. Baumann, All-inkjetprinted bottom-gate thin-film transistors using UV curable dielectric for well-defined sourcedrain electrodes, Journal of Electronic Materials 43(7) (2014) 2631-2636. https://doi.org/10.1007/s11664-014-3143-0.

[11] S. Lilliu, M. B?berl, M. Sramek, S.F. Tedde, J.E. Macdonald, O. Hayden, Inkjet-printed organic photodiodes, Thin Solid Films 520(1) (2011) 610-615. https://doi.org/10.1016/j.tsf.2011.08.004. [12] G. Azzellino, A. Grimoldi, M. Binda, M. Caironi, D. Natali, M. Sampietro, Fully inkjet-printed organic photodetectors with high quantum yield, Advanced Materials 25(47) (2013) 6829-6833. https://doi.org/10.1002/adma.201303473.

[13] K. Domanski, W. Tress, T. Moehl, M. Saliba, M.K. Nazeeruddin, M. Grätzel, Working Principles of Perovskite Photodetectors: Analyzing the Interplay Between Photoconductivity and Voltage-Driven Energy-Level Alignment, Advanced Functional Materials 25(44) (2015) 69366947. https://doi.org/10.1002/adfm.201503188.

[14] Y. Guo, C. Liu, H. Tanaka, E. Nakamura, Air-stable and solution-processable perovskite photodetectors for solar-blind UV and visible light, The journal of physical chemistry letters 6(3) (2015) 535-539. https://doi.org/10.1021/jz502717g.

[15] Z. Yang, Y. Deng, X. Zhang, S. Wang, H. Chen, S. Yang, J. Khurgin, N.X. Fang, X. Zhang, R. Ma, High-Performance Single-Crystalline Perovskite Thin-Film Photodetector, Advanced Materials 30(8) (2018) 1704333 1-7. https://doi.org/10.1002/adma.201704333.

[16] H.S. Nalwa, Photodetectors and fiber optics, Elsevier2012. 
[17] S. Donati, Photodetectors, Prentice Hall PTR1999.

[18] E.-T. Kim, A. Madhukar, Z. Ye, J.C. Campbell, High detectivity InAs quantum dot infrared photodetectors, Applied Physics Letters 84(17) (2004) 3277-3279. https://doi.org/10.1063/1.1719259.

[19] A.J. Makynen, J.T. Kostamovaara, T.E. Rahkonen, CMOS photodetectors for industrial position sensing, IEEE transactions on instrumentation and measurement 43(3) (1994) 489-492. https://doi.org/10.1109/19.293476.

[20] F. Withers, T.H. Bointon, M.F. Craciun, S. Russo, All-graphene photodetectors, ACS nano 7(6) (2013) 5052-5057. https://doi.org/10.1021/nn4005704.

[21] J.P. Zheng, K.L. Jiao, W.P. Shen, W.A. Anderson, H.S. Kwok, Highly sensitive photodetector using porous silicon, Applied Physics Letters 61(4) (1992) 459-461. https://doi.org/10.1063/1.107884.

[22] J. Raynor, P. Seitz, A linear array of photodetectors with wide dynamic range and near photon quantum-noise limit, Sensors and Actuators A: Physical 61(1) (1997) 327-330. https://doi.org/10.1016/S0924-4247(97)01481-7.

[23] D. Cristea, F. Craciunoiu, M. Modreanu, M. Caldararu, I. Cernica, Photonic circuits integrated with CMOS compatible photodetectors, Optical Materials 17(1) (2001) 201-205. https://doi.org/10.1016/S0925-3467(01)00045-3.

[24] G. Pace, A. Grimoldi, D. Natali, M. Sampietro, J.E. Coughlin, G.C. Bazan, M. Caironi, AllOrganic and Fully-Printed Semitransparent Photodetectors Based on Narrow Bandgap Conjugated Molecules, Advanced Materials 26(39) (2014) 6773-6777. https://doi.org/10.1002/adma.201402918.

[25] M. Böberl, M.V. Kovalenko, S. Gamerith, E.J.W. List, W. Heiss, Inkjet-Printed Nanocrystal Photodetectors Operating up to $3 \mu \mathrm{m}$ Wavelengths, Advanced Materials 19(21) (2007) 35743578. https://doi.org/10.1002/adma.200700111.

[26] Z. Huang, J.E. Carey, M. Liu, X. Guo, E. Mazur, J.C. Campbell, Microstructured silicon photodetector, Applied Physics Letters 89(3) (2006) 033506. https://doi.org/10.1063/1.2227629.

[27] Y.H. Ko, G. Nagaraju, J.S. Yu, Wire-shaped ultraviolet photodetectors based on a nanostructured $\mathrm{NiO} / \mathrm{ZnO}$ coaxial $\mathrm{p}-\mathrm{n}$ heterojunction via thermal oxidation and hydrothermal growth processes, Nanoscale 7(6) (2015) 2735-2742. https://doi.org/10.1039/c4nr06662f.

[28] F. Guo, B. Yang, Y. Yuan, Z. Xiao, Q. Dong, Y. Bi, J. Huang, A nanocomposite ultraviolet photodetector based on interfacial trap-controlled charge injection, Nature nanotechnology 7(12) (2012) 798-802. https://doi.org/10.1038/nnano.2012.187.

[29] W. Wohlmuth, M. Arafa, A. Mahajan, P. Fay, I. Adesida, InGaAs metal-semiconductor-metal photodetectors with engineered Schottky barrier heights, Applied physics letters 69(23) (1996) 3578-3580. https://doi.org/10.1063/1.117212.

[30] J. Osmond, L. Vivien, J.-M. Fédéli, D. Marris-Morini, P. Crozat, J.-F. Damlencourt, E. Cassan, J. Mangeney, Y. Lecunff, S. Laval, Ge-on-silicon vertical PIN photodetectors, SPIE proceedings Silicon Photonics IV 7220 (2009) 72200F-1. https://doi.org/10.1117/12.807947.

[31] Y.L. Kong, I.A. Tamargo, H. Kim, B.N. Johnson, M.K. Gupta, T.-W. Koh, H.-A. Chin, D.A. Steingart, B.P. Rand, M.C. McAlpine, 3D printed quantum dot light-emitting diodes, Nano letters 14(12) (2014) 7017-7023. https://doi.org/10.1021/nl5033292.

[32] S.-P. Chen, J.R.D. Retamal, D.-H. Lien, J.-H. He, Y.-C. Liao, Inkjet-printed transparent nanowire thin film features for UV photodetectors, RSC Advances 5(87) (2015) 70707-70712. https://doi.org/10.1039/C5RA12617G.

[33] M. Kim, H.-J. Ha, H.-J. Yun, I.-K. You, K.-J. Baeg, Y.-H. Kim, B.-K. Ju, Flexible organic phototransistors based on a combination of printing methods, Organic Electronics 15(11) (2014) 2677-2684. https://doi.org/10.1016/j.orgel.2014.07.041. 
[34] M. Chen, H. Yu, S.V. Kershaw, H. Xu, S. Gupta, F. Hetsch, A.L. Rogach, N. Zhao, Fast, AirStable Infrared Photodetectors based on Spray-Deposited Aqueous HgTe Quantum Dots, Advanced Functional Materials 24(1) (2014) 53-59. https://doi.org/10.1002/adfm.201301006. [35] L. Chu, R. Hu, W. Liu, Y. Ma, R. Zhang, J. Yang, Screen printing large-area organometal halide perovskite thin films for efficient photodetectors, Materials Research Bulletin 98 (2018) 322327. https://doi.org/10.1016/j.materresbull.2017.10.039.

[36] R.F. Hossain, I.G. Deaguero, T. Boland, A.B. Kaul, Biocompatible, large-format, inkjet printed heterostructure MoS 2-graphene photodetectors on conformable substrates, npj 2D Materials and Applications 1(1) (2017) 28. https://doi.org/10.1038/s41699-017-0034-2.

[37] S.F. Tedde, J. Kern, T. Sterzl, J. Furst, P. Lugli, O. Hayden, Fully spray coated organic photodiodes, Nano letters 9(3) (2009) 980-983. https://doi.org/10.1021/nl803386y.

[38] M. Zhu, X. Li, Y. Guo, X. Li, P. Sun, X. Zang, K. Wang, M. Zhong, D. Wu, H. Zhu, Vertical junction photodetectors based on reduced graphene oxide/silicon Schottky diodes, Nanoscale 6(9) (2014) 4909-4914. https://doi.org/10.1039/C4NR00056K.

[39] K. Zhang, X. Fang, Y. Wang, Y. Wan, Q. Song, W. Zhai, Y. Li, G. Ran, Y. Ye, L. Dai, Ultrasensitive Near-Infrared Photodetectors Based on a Graphene-MoTe2-Graphene Vertical van der Waals Heterostructure, ACS applied materials \& interfaces 9(6) (2017) 5392-5398. https://doi.org/10.1021/acsami.6b14483.

[40] Y. Lin, K.H. Lee, S. Bao, X. Guo, H. Wang, J. Michel, C.S. Tan, High-efficiency normal-incidence vertical pin photodetectors on a germanium-on-insulator platform, Photonics Research 5(6) (2017) 702-709. https://doi.org/10.1364/PRJ.5.000702.

[41] Y.-H. Kim, J.-I. Han, M.-K. Han, J.E. Anthony, J. Park, S.K. Park, Highly light-responsive ink-jet printed 6,13-bis(triisopropylsilylethynyl) pentacene phototransistors with suspended topcontact structure, Organic Electronics 11(9) (2010) 1529-1533. https://doi.org/10.1016/j.orgel.2010.06.016.

[42] M. Caironi, E. Gili, H. Sirringhaus, Ink-jet printing of downscaled organic electronic devices, Organic Electronics II: More Materials and Applications (2012) 281-326. https://doi.org/10.1002/9783527640218.ch9.

[43] R.E. Sousa, C.M. Costa, S. Lanceros-Méndez, Advances and Future Challenges in Printed Batteries, ChemSusChem 8(21) (2015) 3539-3555. https://doi.org/10.1002/cssc.201500657.

[44] L.L. Lavery, G.L. Whiting, A.C. Arias, All ink-jet printed polyfluorene photosensor for high illuminance detection, Organic Electronics 12(4) (2011) 682-685. https://doi.org/10.1016/j.orgel.2011.01.023.

[45] J. Oliveira, V. Correia, E. Sowade, I. Etxebarria, R.D. Rodriguez, K.Y. Mitra, R.R. Baumann, S. Lanceros-Mendez, Indirect X-ray Detectors Based on Inkjet-Printed Photodetectors with a Screen-Printed Scintillator Layer, ACS Applied Materials \& Interfaces 10(15) (2018) 1290412912. https://doi.org/10.1021/acsami.8b00828.

[46] J. Oliveira, V. Correia, H. Castro, P. Martins, S. Lanceros-Mendez, Polymer-based smart materials by printing technologies: Improving application and integration, Additive Manufacturing 21 (2018) 269-283. https://doi.org/10.1016/j.addma.2018.03.012.

[47] P.J. Sebastian, M.E. Calixto, Porous CdS:CdO composite structure formed by screen printing and sintering of CdS in air, Thin Solid Films 360(1-2) (2000) 128-132. https://doi.org/10.1016/S0040-6090(99)01088-3.

[48] H. Du, L.E. Antonuk, Y. El-Mohri, Q. Zhao, Z. Su, J. Yamamoto, Y. Wang, Investigation of the signal behavior at diagnostic energies of prototype, direct detection, active matrix, flat-panel imagers incorporating polycrystalline Hgl2, Physics in Medicine and Biology 53(5) (2008) 13251351. https://doi.org/10.1088/0031-9155/53/5/011.

[49] M. Schieber, A. Zuck, H. Gilboa, G. Zentai, Reviewing Polycrystalline Mercuric lodide X-Ray Detectors, IEEE Transactions on Nuclear Science 53(4) (2006) 2385-2391. https://doi.org/10.1109/TNS.2006.877043. 
[50] Q. Zhao, L.E. Antonuk, Y. El-Mohri, Y. Wang, H. Du, A. Sawant, Z. Su, J. Yamamoto, Performance evaluation of polycrystalline $\mathrm{Hgl} 2$ photoconductors for radiation therapy imaging, Medical Physics 37(6Part1) (2010) 2738-2748. https://doi.org/10.1118/1.3416924.

[51] J.C. Park, P.J. Jeon, J.S. Kim, S. Im, Small-Dose-Sensitive X-Ray Image Pixel with HgI2 Photoconductor and Amorphous Oxide Thin-Film Transistor Advanced Healthcare Materials 4(1) (2015) 51-57. https://doi.org/10.1002/adhm.201400077.

[52] D. Baierl, L. Pancheri, M. Schmidt, D. Stoppa, G.-F. Dalla Betta, G. Scarpa, P. Lugli, A hybrid CMOS-imager with a solution-processable polymer as photoactive layer, Nature Communications 3 (2012) 1175-1175. https://doi.org/10.1038/ncomms2180.

[53] Z. Liu, K. Parvez, R. Li, R. Dong, X. Feng, K. M?llen, Transparent Conductive Electrodes from Graphene/PEDOT:PSS Hybrid Inks for Ultrathin Organic Photodetectors, Advanced Materials 27(4) (2015) 669-675. https://doi.org/10.1002/adma.201403826.

[54] R. Aga, C. Jordan, R.S. Aga, C.M. Bartsch, E.M. Heckman, Metal Electrode Work Function Modification Using Aerosol Jet Printing, IEEE Electron Device Letters 35(11) (2014) 1124-1126. https://doi.org/10.1109/LED.2014.2355142.

[55] R.C. Tenent, T.M. Barnes, J.D. Bergeson, A.J. Ferguson, B. To, L.M. Gedvilas, M.J. Heben, J.L. Blackburn, Ultrasmooth, Large-Area, High-Uniformity, Conductive Transparent Single-WalledCarbon-Nanotube Films for Photovoltaics Produced by Ultrasonic Spraying, Advanced Materials 21(31) (2009) 3210-3216. https://doi.org/10.1002/adma.200803551.

[56] S. Kim, J. Yim, X. Wang, D.D.C. Bradley, S. Lee, J.C. deMello, Spin- and Spray-Deposited Single-Walled Carbon-Nanotube Electrodes for Organic Solar Cells, Advanced Functional Materials 20(14) (2010) 2310-2316. https://doi.org/10.1002/adfm.200902369.

[57] A. Falco, L. Cin, G. Scarpa, P. Lugli, A. Abdellah, Fully-Sprayed and Flexible Organic Photodiodes with Transparent Carbon Nanotube Electrodes, ACS Applied Materials \& Interfaces 6(13) (2014) 10593-10601. https://doi.org/10.1021/am5022123.

[58] M. Schmidt, A. Falco, M. Loch, P. Lugli, G. Scarpa, Spray coated indium-tin-oxide-free organic photodiodes with PEDOT:PSS anodes, AIP Advances 4(10) (2014) 107132-107132. https://doi.org/10.1063/1.4899044.

[59] S. Inamdar, K. Rajpure, High-performance metal-semiconductor-metal UV photodetector based on spray deposited ZnO thin films, Journal of Alloys and Compounds 595 (2014) 55-59. https://doi.org/10.1016/j.jallcom.2014.01.147.

[60] S.S. Shinde, K.Y. Rajpure, Fabrication and performance of N-doped ZnO UV photoconductive detector, Journal of Alloys and Compounds 522 (2012) 118-122. https://doi.org/10.1016/j.jallcom.2012.01.118.

[61] J.R. Wojciechowski, L.C. Shriver-Lake, M.Y. Yamaguchi, E. Füreder, R. Pieler, M. Schamesberger, C. Winder, H.J.r. Prall, M. Sonnleitner, F.S. Ligler, Organic photodiodes for biosensor miniaturization, Analytical chemistry 81(9) (2009) 3455-3461. https://doi.org/10.1021/ac8027323.

[62] H. Wang, C. Cheng, L. Zhang, H. Liu, Y. Zhao, Y. Guo, W. Hu, G. Yu, Y. Liu, Inkjet Printing Short-Channel Polymer Transistors with High-Performance and Ultrahigh Photoresponsivity, Advanced Materials 26(27) (2014) 4683-4689. https://doi.org/10.1002/adma.201400697.

[63] A. Gohier, A. Dhar, L. Gorintin, P. Bondavalli, Y. Bonnassieux, C.S. Cojocaru, All-printed infrared sensor based on multiwalled carbon nanotubes, Applied Physics Letters 98(6) (2011) 063103. https://doi.org/10.1063/1.3552686.

[64] G. Hu, T. Albrow-Owen, X. Jin, A. Ali, Y. Hu, R.C. Howe, K. Shehzad, Z. Yang, X. Zhu, R.I. Woodward, Black phosphorus ink formulation for inkjet printing of optoelectronics and photonics, Nature communications 8(1) (2017) 278. https://doi.org/10.1038/s41467-01700358-1.

[65] M. Kielar, O. Dhez, L. Hirsch, Ultra-efficient all-printed organic photodetectors, Organic Sensors and Bioelectronics IX, International Society for Optics and Photonics, 2016, p. 994409. 
[66] A. Pierre, A.C. Arias, High-detectivity printed organic photodiodes for large area flexible imagers, Electron Devices Meeting (IEDM), 2016 IEEE International (2016) 32.4.1-32.4.4. https://doi.org/10.1109/IEDM.2016.7838528.

[67] J. Cabanillas-Gonzalez, G. Grancini, G. Lanzani, Pump-Probe Spectroscopy in Organic Semiconductors: Monitoring Fundamental Processes of Relevance in Optoelectronics, Advanced Materials 23(46) (2011) 5468-5485. https://doi.org/10.1002/adma.201102015.

[68] T. Virgili, J. Cabanillas-Gonzalez, L. Lüer, G. Lanzani, Photophysics of Molecular Materials: From Single Molecules to Single Crystals Chapter 10 - Ultrafast Optoelectronic Probing of Excited States in Low-Dimensional Carbon-Based $\pi$-Conjugated Materials, Wiley-VCH Verlag GmbH \& Co. KGaA2006.

[69] A. Larsson, P.A. Andrekson, S.T. Eng, A. Yariv, Tunable superlattice pin photodetectors: characteristics, theory, and application, IEEE journal of quantum electronics 24(5) (1988) 787801. https://doi.org/10.1109/3.195.

[70] B. Hosticka, W. Brockherde, A. Bussmann, T. Heimann, R. Jeremias, A. Kemna, C. Nitta, O. Schrey, CMOS imaging for automotive applications, IEEE Transactions on Electron Devices 50(1) (2003) 173-183. https://doi.org/10.1109/TED.2002.807258.

[71] K. Schroeter, Printed sensors: Enabling new applications, Sensor Review 28(1) (2008) 6-11. https://doi.org/10.1108/02602280810849956.

TOC

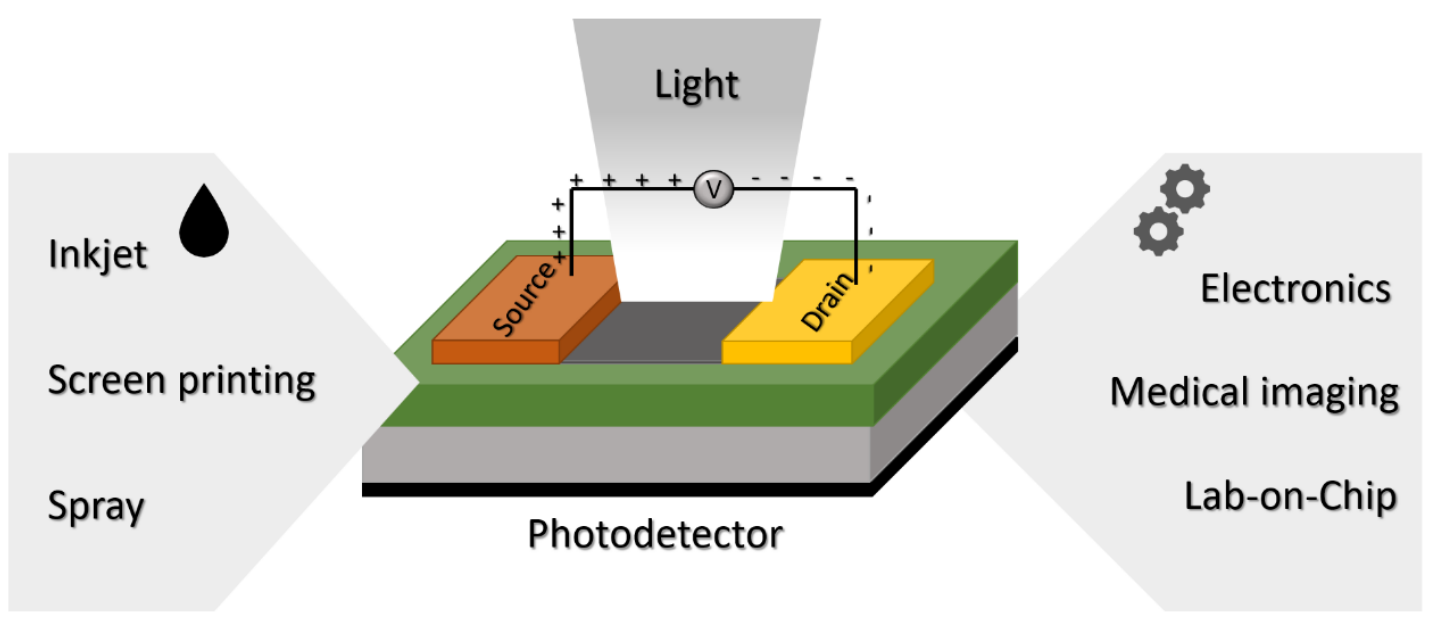

